\title{
Fighting impunity in hate crime - history, ethics, and the law: An interview with Harsh Mander
}

\section{Mohsin Alam Bhat ${ }^{1}$}

Published online: 20 August 2020

(c) O.P. Jindal Global University (JGU) 2020

\begin{abstract}
This interview with writer and activist Harsh Mander was conducted on 21 and 23 April 2020 while numerous instances of hate crime, during the severe COVID-19 lockdown, were coming to light. This came on the heels of the popular protests against the Citizenship Amendment Act, 2019, and the February 2020 violence in Delhi. The interview situates the present moment, tying together history, socio-legal assessments of sectarian violence, evaluation of legal reform, and the ethics of antihate activism. First, Mander draws from his extensive experience - as a former bureaucrat, anti-hate advocate, and legal activist - to offer the larger historical trajectory of sectarian violence in India. His account highlights the role of the rising majoritarian state ideology in facilitating and celebrating sectarian hostilities. He also develops an account of how we should understand the social and personal harms of mass violence and the phenomenon of lynching. Second, he discusses the contentious question of legal reform for ending impunity in hate crime cases. Specifically, he notes the problem of state complicity in violence and the failed attempts to legislate an anti-communal violence law. Third, he elaborates on the protracted challenges of building viable strategies of litigation in the aftermath of sectarian violence. He evaluates Nyayagraha (literally meaning struggle for justice), his unique experiment after the 2002 Gujarat pogrom based on an ethical practice for legal justice.
\end{abstract}

Keywords Communal riots $\cdot$ Hate crimes $\cdot$ Displacement $\cdot$ Impunity $\cdot$ Community justice

M Mohsin Alam Bhat

mabhat@jgu.edu.in

1 Jindal Global Law School, O.P. Jindal Global University, Sonipat, India 


\section{Introduction}

My first introduction to Harsh Mander was as the chronicler of India's marginalised. Excerpts from his book Unheard Voices ${ }^{1}$ were part of the course on law and poverty offered by Professor Amita Dhanda. ${ }^{2}$ The book offered a window into the lives of the victims of caste and communal violence, hunger and poverty, sexual violence, and human-made calamities. Ironically, for many of the future lawyers in the classroom, these unusual readings in an unconventional law school course were the most memorable pedagogical experiences. The course was perhaps the first time many of us - mostly privileged, English-speaking, and urban law students - were exposed to the realities of our country. Personally for me, it was also the first time that I truly appreciated the Janus-faced nature of the law. It was a tool of oppression that often hid power and hierarchy. But it was also a formidable instrument of resistance.

Mander quit the prestigious Indian Administrative Services (IAS) — the elite bureaucratic services in India - in response to the State's complicity in the 2002 Gujarat riots. Years later, when I had the opportunity to work with him, Mander told me that many of his friends - all highly educated and liberal — distanced themselves from him. They thought Mander's public repudiation was a misplaced provocation. In response, he spent the next many months in Gujarat building Nyayagraha - a widely noted collaborative experiment for legal justice in communal riots cases. ${ }^{3}$ Nyayagraha succeeded in getting the Supreme Court to reopen more than 2000 cases that the Gujarat police had summarily closed without any prosecution. ${ }^{4}$

Mander has continued to chronicle the tragedy of sectarian violence in Gujarat, the seemingly insurmountable barriers to justice, and the social and political consequences for the country. In 2017, Mander - along with a number of senior academics, journalists, and activists - inaugurated Karwan-e-Mohabbat (Caravan of Love). ${ }^{5}$ Karwan visited the victims and survivors of lynching, offered solidarity and legal support, and chronicled what looked like a rising tide of hate crime in the country.

In December 2019, the Indian Parliament passed the Citizenship Amendment Act, 2019, which for the first time in the Republic's history incorporated a religious test for citizenship. For many, this was a great betrayal of India's secular and

\footnotetext{
1 Harsh Mander, Unheard Voices: Stories of Forgotten Lives (Penguin India 2001).

2 Professor Amita Dhanda teaches at the National Academy of Legal Studies and Research (NALSAR), Hyderabad. See NALSAR University of Law, 'Amita Dhanda'. https://www.nalsar.ac.in/amita-dhanda. Accessed 20 July 2020.

${ }^{3}$ Harsh Mander, Towards Healing? Seeking Paths for Justice and Reconciliation in Gujarat (WISCOMP 2008).

4 See National Human Rights Commission v State of Gujarat and Others Criminal Miscellaneous Petition No. 3741 of 2004 in Writ Petition (Criminal) No. 109 of 2003. Also see Harsh Mander, 'From Godhra to Una: The Face of the Gujarat Riots Has Attached His Name to the Dalit Cause' (Scroll.in, 28 August 2016). https://scroll.in/article/813919/from-godhra-to-una-the-face-of-the-gujarat-riots-has-attac hed-his-name-to-the-dalit-cause. Accessed 15 July 2020.

5 See Karwan-e-Mohabbat, 'About Us'. https://karwanemohabbat.in/about/. Accessed 20 July 2020.
} 
inclusive Constitution. ${ }^{6}$ Within weeks, an ocean of peaceful protests erupted across the country. Protestors — led by old and young Muslim women — held the national flag and sang the national anthem, asserting their national belonging as equal citizens. Mander became one of the definitive faces of the protests.

The inspiring protests were soon broken - first by COVID-19 and then by the horrifying backlash in the form of the violence in Delhi in February 2020. In June 2020, the Delhi Police named Mander in the charge sheet of one of the riot cases. While at the time of writing the police had not named Mander as an accused, the charge sheet appeared to suggest that Mander's speech during the protests incited violence. ${ }^{7}$ Ironically, this is how Mander had ended the speech to the protestors,

We have only one answer to their hatred, and that answer is love.

They will cause violence, they will incite us to violence, but we will never commit violence. Please understand that it is their ploy to incite you to violence. If we respond with violence, we will create $2 \%$ violence and they will respond with $100 \%$ violence.

We have learnt from Gandhi what violence and injustice can do.

Most importantly, we have to fight with non-violence. Anyone who incites you

to violence and hatred is not a friend of yours.

I will raise a slogan now: The Constitution

[crowd responds] Long live ${ }^{8}$

\section{Interview}

M Mohsin Alam Bhat (MAB): I looked back at your large body of work - your written academic prose, and popular pieces as an advocate and human rights activist. One of the most iconic is 'Cry, The Beloved Country' that you wrote after the 2002 Gujarat pogrom. ${ }^{9}$ You began that essay with a striking sentence that suggested a sense of aching, tragedy, and responsibility. You wrote, 'My heart is sickened, my

\footnotetext{
${ }^{6}$ See Niraja Gopal Jayal, 'Citizenship Amendment Act: 'Principle of Discrimination Based on Faith will be Difficult to Limit' (The Indian Express, 24 December 2019). https://indianexpress.com/article/expla ined/indian-constitution-citizenship-amendment-act-modi-govt-6181761/. Accessed 20 July 2020.

${ }^{7}$ Sruthisagar Yamunan, 'Delhi Violence: In One Charge Sheet, Police Claim Muslim Protestors Provoked Riots' (Scroll.in, 10 June 2020). https://scroll.in/article/964042/delhi-violence-in-one-charge-sheet -police-claim-muslim-protestors-provoked-riots. Accessed 20 July 2020; Sarim Naved, 'The Good, Bad and Ugly of the Delhi Police Riot Chargesheets' (The Wire, 24 June 2020). https://thewire.in/communalis m/the-good-bad-and-ugly-of-the-delhi-police-riot-chargesheets. Accessed 20 July 2020.

${ }^{8}$ Original in Hindi. For the original speech as well its English translation, see The Wire Staff, "Constitution, Love, Ahimsa': Harsh Mander's Speech Which Centre Now Claims 'Incited Violence" (The Wire, 5 March 2020). https://thewire.in/rights/harsh-mander-jamia-speech-supreme-court-full-translatio n. Accessed 20 July 2020.

${ }^{9}$ Harsh Mander, 'Cry, The Beloved Country: Reflections on the Gujarat Massacre by a Serving IAS Officer' (Outlook, 19 March 2002). https://www.outlookindia.com/website/story/cry-the-beloved-count ry/214944. Accessed 12 July 2020.
} 
soul wearied, my shoulders aching with the burdens of guilt and shame. ${ }^{10}$ What is your assessment of how the conversation around sectarian violence, hate crime, and impunity has evolved since then? How would you place the current moment in the longer history of sectarian violence in India?

Harsh Mander (HM): I think the movement for the demolition of the Babri Masjid and its actual demolition marks a very decisive shift. ${ }^{11}$ It was a shift not only in the conversations and sensitivity about the pattern of violence, but also in the operational idea of a secular democratic country that guarantees equal rights, respect, security, and participation for religious minorities in letter and spirit. Since the demolition of the Babri Masjid, there has been a continuous decline. 2002 was a very important milestone in that journey, which also led me in my personal life to move out of the government to join this battle as an independent citizen. There has been an increasing decline in multiple ways. There is growing normalisation of hate speech, violence, and everyday discrimination in society, and by the State and all its institutions, including the judiciary. Many moments — 1989 when the Babri Masjid issue was politicised, 1992 when the Masjid was demolished, the 2002 Gujarat massacre, the 2014 Muzaffarnagar violence in Uttar Pradesh, the 2012 Kokrajhar violence in Assam, the 2008 violence against Christians in Kandhamal in Odisha — were key milestones. But the 2014 and 2019 national elections represent a very decisive and precipitous decline in the lived reality of the religious minorities, particularly the Muslims, and also to some degree the Indian Christians. The everyday normalisation and routinisation of hate violence and hate speech, I think, suggests that there has been a steady decline.

In terms of the history of sectarian violence, we need to go further back. I would interpret this history as four stages of communal violence. ${ }^{12}$ The Partition in 1947 was a dystopian time in our history. Millions of people died in the Hindu-Muslim riots in its aftermath. It was Mahatma Gandhi's resolve that India would belong equally to both Hindu and Muslim citizens. His last fast before his assassination was an extraordinarily important moment. A few months before he died, he told someone that his work would not be complete until Muslims would be able to walk without fear in their heart in Delhi and the country. ${ }^{13}$ His last fast included the demand

\footnotetext{
10 ibid.

11 For the antecedents and implications of the Hindu nationalist Ayodhya movement for the demolition of the Babri mosque, see Thomas Blom Hansen, The Saffron Wave: Democracy and Hindu Nationalism in Modern India (Princeton University Press 1999) 154-199.

12 For some key literature on the subject, see Paul R Brass, The Production of Hindu-Muslim Violence in Contemporary India (University of Washington Press 2003); Ashutosh Varshney, Ethnic Conflict and Civic Life: Hindus and Muslims in India (Yale University Press 2002); Steven I Wilkinson, Votes and Violence: Electoral Competition and Ethnic Riots in India (Cambridge University Press 2004); Asghar Ali Engineer (ed) Communal Riots in Post-Independence India (Sangam Books 1984).

13 This is a reference to a speech given by Gandhi on 13 January 1948 at the prayer meeting in Delhi while he was fasting for peace in the city. Gandhi said, 'I shall terminate the fast only when peace has returned to Delhi. If peace is restored to Delhi it will have effect not only on the whole of India but also on Pakistan and when that happens, a Muslim can walk around in the city all by himself. I shall then terminate the fast...So my wish is that Hindus, Sikhs, Parsis, Christians and Muslims who are in India should continue to live in India and India should become a country where everyone's life and property are safe. Only then will India progress.' See Collected Works of Mahatma Gandhi, vol 98, 227. https://
} 
for restoring the places of worship that had been taken away by the rioters from the Muslims and converted into Hindus temples. He also demanded the return of the homes and properties Muslims lost during the riots. His was a battle for equal rights in every respect in our country, based on equality and true fraternity. I think his assassination was the turning point. After that, the Constituent Assembly that drafted the Indian constitution included very strong protections for the minorities. ${ }^{14}$ It looked like the question had been resolved, and the Rashtriya Swayamsewak Sangh (RSS) and the Hindu Mahasabha went into the shadows of Indian public life. And of course, there was also the leadership of Jawahar Lal Nehru in the first decade and a half.

The first major incident of communal violence in independent India happened in 1961 towards the last part of Nehru's life. ${ }^{15}$ The first days of communal violence from 1961 to 1983 led to considerable loss of life and property for Muslims. To some extent, they were in the nature of riots. There was some degree of loss of life of the Hindu community as well, although the proportion was much higher for the minority Muslims. 1983 saw the Nellie massacre that was a completely one-sided killing — and a very brutal one — of Muslims in Assam. ${ }^{16} 1984$ saw the anti-Sikh massacre in Delhi and other parts of the country. ${ }^{17}$ There were many other episodes of communal violence, including in Bhagalpur. ${ }^{18}$ After the demolition of the Babri Masjid, massive communal massacres were witnessed in places like Bombay (now Mumbai) and Bhopal. ${ }^{19}$ And then, we had communal violence in 2002. ${ }^{20}$ This

\footnotetext{
Footnote 13 (continued)

www.gandhiashramsevagram.org/gandhi-literature/collected-works-of-mahatma-gandhi-volume-1-to-98. php. Accessed 12 July 2020.

14 For a discussion of the Constituent Assembly and the drafting of the Constitution, see Granville Austin, The Indian Constitution: Cornerstone of a Nation (Oxford University Press 1999).

15 The first major communal riot in post-colonial India occurred in the town of Jabalpur in the state of Madhya Pradesh in 1961. See Christophe Jaffrelot, The Hindu Nationalist Movement and Indian Politics: 1925 to the 1990s: Strategies of Identity-Building, Implantation and Mobilisation (With Special Reference to Central India) (C Hurst \& Co 1996) 166.

16 See Makiko Kimura, The Nellie Massacre of 1983: Agency of Rioters (SAGE Publications India 2013).

17 See Virginia van Dyke, 'The Anti-Sikh Riots of 1984 in Delhi: Politicians, Criminals, and the Discourse of Communalism' in Paul R Brass (ed), Riots and Pogroms (Palgrave Macmillan 1996). Also see Justice GT Nanavati, Report of the Justice Nanavati Commission of Inquiry (1984 Anti-Sikh Riots): Volumes I and II (2005).

18 See Asghar Ali Engineer, 'Bhagalpur Riot Inquiry Commission Report' (1995) 30(28) Economic and Political Weekly 1729; Warisha Farasat, 'The Forgotten Carnage of Bhagalpur' (2013) 48(3) Economic and Political Weekly 34.

19 See Asghar Ali Engineer, 'Bombay Shames India' (1993) 28(3) Economic and Political Weekly 81; State Bureau Reports, 'Babri Masjid Demolition Aftermath: Religious Hatred Engulfs India, Over 1,000 People Die' (India Today, 31 December 1992). https://www.indiatoday.in/magazine/cover-story/story /19921231-babri-masjid-demolition-aftermath-religious-hatred-engulfs-india-over-1000-people-die767313-2012-12-21. Accessed 13 July 2020.

20 For studies on the 2002 Gujarat pogrom, see Achyut Yagnik and Suchitra Sheth, 'Whither Gujarat? Violence and After' (2002) 37(11) Economic and Political Weekly 1009.
} 
spans a period of large one-sided communal massacres very much in the nature of pogroms. ${ }^{21}$ This marks the second phase.

After the 2002 pogrom, a large number of human rights organisations felt that this was a turning point in our history. They knew that if they do not fight back, we would lose everything we had fought for in the secular imagination. There was a lot of concerted action. There was the National Human Rights Commission (NHRC) and the Supreme Court. ${ }^{22}$ There was far more active media reporting about what had happened. ${ }^{23}$ In the end, it is true that Mr. Narendra Modi and indeed a range of police officers and the others guilty could not be substantially punished. ${ }^{24}$ Most of the cases have not been successful. ${ }^{25}$ But there was still enough action to make this kind of communal massacre very costly for those who led them. Mr. Modi was denied a visa from the United States (US) in this entire period and in fact by most European countries. ${ }^{26} \mathrm{He}$ was a pariah.

\footnotetext{
${ }^{21}$ For an accessible list of major incidents of communal violence till the mid-1980s, see Violette Graff and Juliette Galonnier, 'Hindu-Muslim Communal Riots In India I (1947-1986)' (SciencesPo, 15 July 2013). https://www.sciencespo.fr/mass-violence-war-massacre-resistance/en/document/hindu-musli m-communal-riots-india-i-1947-1986.html\#: :text=1961\%3B\%20February\%204\%E2\%80\%939\%3A\%20 Jabalpur\%20(Madhya\%20Pradesh)\&text=The\%20first\%20major\%2Dscale\%20riot,the $\% 20$ state $\% 20$ of\%20Madhya\%20Pradesh. Accessed 13 July 2020. For major incidents of communal violence from 1986, see Violette Graff and Juliette Galonnier, 'Hindu-Muslim Communal Riots In India II (19862011)' (SciencesPo, 20 August 2013). https://www.sciencespo.fr/mass-violence-war-massacre-resistance /en/document/hindu-muslim-communal-riots-india-ii-1986-2011.html. Accessed 13 July 2020. In 2007, the central government constituted National Integration Council published a report studying the inquiry commission reports for major communal riots; see Ministry of Home Affairs, Report of Working Group of National Integration Council to Study Reports of the Commissions of Inquiry on Communal Riots (2007).

22 The 2001-2002 Annual Report of the NHRC detailed the proceedings wherein the Commission had taken sиo motu cognisance of the human rights situation in Gujarat and gave specific recommendation to prevent communal violence from being re-ignited. See NHRC, 'Proceedings of the Commission on Gujarat' in National Human Rights Commission Annual Report 2001-2002 (2002) 268-319. For an account of the steps taken by the Supreme Court in the interest of justice for the victims of Gujarat 2002, see Christophe Jaffrelot, 'Gujarat 2002: What Justice for the Victims? The Supreme Court, the SIT, the Police and the State Judiciary' (2012) 47(8) Economic and Political Weekly 77, 81-84.

${ }^{23}$ For the 'stupendous' coverage of Gujarat 2002, see Saifuddin Ahmed, 'The Role of the Media during Communal Riots in India: A Study of the 1984 Sikh Riots and the 2002 Gujarat Riots' (2010) 37(2) Media Asia 103, 106-108.

${ }^{24}$ For an account of the mixed judicial record in convicting those accused in Gujarat 2002, see Mahesh Langa, 'Justice Nanvati-Mehta Commission Gives Clean Chit to Narendra Modi in 2002 Gujarat Riots' The Hindu (Ahmedabad, 11 December 2019). https://www.thehindu.com/news/national/2002-gujaratriots-state-govt-to-table-justice-nanavati-mehta-commission-report-in-assembly-today/article30274396 .ece. Accessed 13 July 2020; Scroll Staff, '2002 Gujarat Riots: 17 Convicts Get Bail in Sardarpura Massacre, Asked to do Social, Spiritual Work' (Scroll.in, 28 January 2020). https://scroll.in/latest/95134 9/2002-gujarat-riots-sc-grants-bail-to-14-convicts-in-sardarpura-massacre-case. Accessed 13 July 2020.

${ }^{25}$ To understand why the 'results of judicial proceedings are very few' in relation to Gujarat 2002, see Jaffrelot (n 22).

${ }^{26}$ James Mann, 'Why Narendra Modi Was Banned from the U.S.' (The Wall Street Journal, 2 May 2014). $\quad$ https://www.wsj.com/articles/why-narendra-modi-was-banned-from-the-u-s-1399062010. Accessed 15 July 2020; Ross Colvin, 'Quiet Lunch Shatters EU Boycott of Narendra Modi' (Reuters, 8 February 2013). https://in.reuters.com/article/india-narendra-modi-eu/quiet-lunch-shatters-eu-boycott-ofnarendra-modi-idINDEE91707X20130208. Accessed 15 July 2020.
} 
We see a very decisive shift since 2002 . We stopped witnessing large massacres. All the episodes where communal violence has happened since 2002 until 2014 have been episodes where the loss of life has been actually much smaller. In each of these incidents, fewer than 100 people were killed, which is considerably lower than what we had seen before. But there has been an enormous displacement of people from their homes to a much larger degree. People have not been allowed to return to their homes after the attacks. The kind of normal processes that people had earlier - where people could settle down after the violence and restart their life - have considerably diminished. These violent episodes, despite much less loss of life, have led to permanent separation of populations. Displaced people have had to move to foreign places, forced to stay in Muslim majority areas as refugees. This happened with the survivors of Gujarat, and then Muzaffarnagar, Kandhamal, and Kokrajhar. ${ }^{27}$ I think that is the third phase.

After 2014, we see the fourth phase. This is the phase of lynching. The casualty figure has gone down to one digit. If you actually add up the number of lives lost in each of the episodes of lynching, all of them taken together would still not amount to very large number. ${ }^{28} \mathrm{~A}$ single massacre of the past has seen more loss of life and property than all incidents of lynching together. But lynching has been powerful in deepening, consolidating, normalising, valorising, and legitimising hate. Episodes of communal violence - however brutal they were and however much rupture they caused - were always bound by geography and time. They occurred in a location, there was a beginning and an end, and eventually things settled down. Lynching has broken the boundaries of geography and time. These incidents communicate that if you belong to a particular religious identity, you are now no longer safe at any place and at any time. Anyone can walk into your kitchen and see what meat you are cooking, and lynch you to death. You may be on a train, and you may be lynched. You may be on the road and visibly Muslim, and may be lynched. Each of these episodes of lynching are performative acts. They are videotaped, celebrated, widely circulated on the Internet, and widely consumed.

I found very close parallels with the lynching of African-Americans in the US. During the late-19th and mid-20th centuries, there were incidents of lynching in the

\footnotetext{
27 Damayantee Dhar, 'Sixteen Years After 2002 Gujarat Riots, Victims in Rehabilitation Colonies Still Fear Displacement' (The Wire, 28 February 2018). https://thewire.in/communalism/sixteen-years-after -2002-gujarat-riots-victims-in-rehabilitation-colonies-still-fear-displacement. Accessed 15 July 2020; Sanjeevini Badigar, 'A 'Normal' Anomaly: Displacement Due to Communal Violence in Gujarat' (2012) 47(3) Economic and Political Weekly 42; Special Correspondent, 'Riot Victims Live in Ghetto-Like Conditions: Report' (The Hindu, 8 September 2016). https://www.thehindu.com/news/national/Riot-victi ms-live-in-ghetto-like-conditions-Report/article14626821.ece. Accessed 15 July 2020; Kedar Nagarajan, 'Justice Continues to Elude Victims of Kandhamal Violence' (The Wire, 11 September 2015). https:// thewire.in/communalism/justice-continues-to-elude-victims-of-kandhamal-violence. Accessed 15 July 2020; Monirul Hussain, 'State, Identity Movements and Internal Displacement in the North-East' (2000) 35(51) Economic and Political Weekly 4519.

28 The Quint is maintaining detailed records of incidents of mob violence across India since 2015; the number of deaths by mob lynching, till the date of publication of this interview, is 113 . See 'Hunted: India's Lynching Files' (The Quint, 2018-till date). https://www.thequint.com/quintlab/lynching-in-india I. Accessed 15 July 2020.
} 
US but their numbers were not very high. ${ }^{29}$ Recorded episodes of lynching in the US work to about 50 incidents a year. ${ }^{30}$ But their impact was huge. They led to millions of people leaving the south of the US for the north. ${ }^{31}$ They led to the setting of fear in the African-American heart because of their symbolic character.

This, I would say, is a very brief historical picture of communal violence. As with all such classifications, this is not very neat. But in terms of broad trends, I think this is what I have found.

MAB: In your article 'Conflict and Suffering', ${ }^{32}$ you had given a perceptive account of the direct and indirect harms of mass sectarian violence. You had used phrases like 'vicarious victimhood'33 and 'graded suffering',34 to capture how violence affects people who may not even be directly the victims. Recently, you have written about the symbolic impact of such incidents, referring to the work of American scholars like Amy Woods. ${ }^{35}$ In light of your thesis, how would you theorise about the more localised, individualised hate crime incidents or incidents of lynching? How would you compare the harm of these cases compared to mass violence?

I think it was in 'Conflict and Suffering' that we note another striking observation is one of the impacts of violence in Gujarat and your experience was that people have a deep sense of hurt that their Hindu neighbours or people who were celebrating festivals are not coming and asking for chanda (donations) ${ }^{36}$. So there seems to be a continuing rupture of social relationships after sectarian violence and many of the victims felt boycotted and left out that they gave money in charity or donations for Hindu religious festivals and now nobody cares for them anymore. That I think is a very perceptive observation.

HM: In 'Conflict and Suffering', I wanted to make a few points. One, the suffering people undergo because of hate violence is very different qualitatively from the suffering as a result of other kinds of violence. Suppose there is a massive earthquake. I lost my home and loved ones. There will be enormous anguish in me. But if I lost my home and loved ones due to the violence of my neighbours, to the hate ideology of the State and the enabling of this violence by the police, it is a very different kind of suffering. This is what I have observed in all the many years I worked with the survivors of violence. There is something in that grief that is much harder to find meaning for and closure to. I also talked about direct victims and vicarious

\footnotetext{
29 Jamiles Lartey and Sam Morris, 'How White Americans Used Lynchings to Terrorize and Control Black People' (The Guardian, 26 April 2018). https://www.theguardian.com/us-news/2018/apr/26/lynch ings-memorial-us-south-montgomery-alabama. Accessed 15 July 2020. This article is based on a report by the Equal Justice Initiative on lynchings in America; see EJI, Lynching in America: Confronting the Legacy of Racial Terror (3rd edn, 2017).

30 ibid.

31 ibid.

32 Harsh Mander, 'Conflict and Suffering: Survivors of Carnages in 1984 and 2002' (2010) 45(32) Economic and Political Weekly 57.

33 ibid 58.

34 ibid 59.

35 See Harsh Mander, 'A Shameful Marker of Five Years' (The Hindu, 19 April 2019). https://www.thehi ndu.com/opinion/lead/a-shameful-marker-of-five-years/article26879575.ece. Accessed 15 July 2020.

36 Mander (n 32) 62.
} 
victims. This struck me time after time after the Gujarat violence. While working with the survivors, I met people who had migrated to the US and had not come back to India for many years. They were people who had not lost anything from violence. But the violence had affected them personally. It had caused suffering as if there was something that had happened to them personally. The immediacy of that suffering, I found, led to clinical depression after the Gujarat violence because they felt it was a betrayal of the country they believed India was since their childhood. That sense of betrayal was a very personal one. That was what I had described as 'vicarious' suffering.

Lynching is an instrument of hate violence that lends itself to a massive expansion of the scale, reach, and depth of this vicarious suffering. Every lynching in India is a performative act of public display. A single incident of lynching of an African-American reverberated across the rivers, mountains, deserts - in the heart of every African-American. The same is for India, where the effect of one lynching is carried across the land as if it were thousands of incidents. I found that Muslims have experienced each lynching in a deeply personal way. This nature of vicarious suffering has expanded precisely because lynching breaks the boundaries of geography and time. It potentially communicates that this can happen to any person of this identity and that nobody is safe at any time.

I wish to underline, with some risk of generalisation, that this was the decisive shift after 2002. In the earlier episodes of communal violence, the attempt was to inflict as much harm and damage as possible at the time of the violence. After 2002, the attempt is to sustain the suffering and the loss not just in material terms. It is to divide your activity and social relations with your neighbours. The greatest worry among the victims I worked with used to be why people were not coming to their weddings any longer. I remember one instance when somebody actually went so far as to print two wedding cards - one card with Hindu religious symbols and no Muslim religious symbols — that she sent out to Hindu neighbours, hoping that at least that would encourage them to come to the wedding. But they still did not come in large numbers. Particularly in rural India, it means a lot if your neighbours come at your wedding, serve the bridegroom's family, and participate in the festivities. These are symbols of being one people. With every episode of communal violence after 2002, there has been a systematic campaign to not allow these social relationships of shared life between the two communities to mend and restart.

People have also not been encouraged or allowed to return after the violence. So, the displacement is larger. I remember my many conversations in Gujarat and Muzaffarnagar where more than 50 or 60 percent people were displaced and never able to return to their homes. I asked one person why he was not going back home. His reply was 'Koi bulaye tab toh mai jaaon. Koi bulane hi nahi aaya (If someone invites me back, I will go. No one is even calling me back).' This idea that my neighbours - who were part of my life and whose children's weddings I participated in - now do not care anymore even when I have been living in a relief colony. That nobody has found it fit to ask how I am doing and when I will return. It is that kind of grief that I am talking about. This is the characteristic of the third phase.

There is also a deep ongoing rupture in the nature of social and economic relations, in the form of boycott. For years, people in Muzaffarnagar have stopped 
employing people of the other communities for a range of labour like specialised kinds of artisanship. Even if this may cause some kind of economic inconvenience, the attempt is to not give them work, to not buy their services and labour. This is in addition to the social boycott of not participating in social activities. This is really striking in the new century of how hate violence has in a sense separated communities.

We must understand the implications of this. We now have children growing up in segregated settlements. So, the word we hear all the time in Gujarat is "border" to describe lines of segregation. This is not just in Ahmedabad, but also in towns and villages. There is a sense of a border that Muslims are pushed to. They are no longer welcome in mixed colonies where there has been violence or fear of violence. So, children are growing up without having friends from another community. The lasting impact of this, in terms of the kind of India that Mahatma Gandhi dreamt for us, is destroyed when communities do not have the opportunity of meeting or building social relations across the spectrum of the religious divide. And therefore, in a moment like the COVID-19 lockdown, it is possible to persuade a large majority of Hindus that somehow Muslims are responsible for consciously and concertedly spreading the virus. ${ }^{37}$ How could so many ordinary Hindus - who may not even see themselves as communal — be persuaded so easily about the role of Muslims in spreading the virus in this time of great fear and death? I see two kinds of scenarios that are being built which make Muslims the villains. The softer one is that there is so much religious bigotry among Muslims that they have large gatherings and are not mindful of the necessity of social distancing. But there is a further much more evil kind of portrayal. According to it, Muslims actually want to engage in a new form of jihad where they want to kill non-Muslims by introducing the virus into schools or on vegetables through their saliva. ${ }^{38}$ It's so bizarre that people are actually refusing to buy vegetables from Muslims. ${ }^{39}$ People are putting up flags to show the identity of the person selling vegetables. All in the course of the last few weeks! I am just amazed how millions of ordinary Hindus could be so persuaded. I think it is part of this long project where once you have started this social segregation, Muslims are not people you know, have grown with or count among your friends. It becomes easier and easier for such demonising imagery to actually find wide persuasion or support. We cannot even say that the RSS went house to house persuading people of this during the lockdown. Clearly, the soil was fertile to accept this completely bizarre set of prejudices about our Muslims neighbours. We will need a long time to understand how it is possible to conduct this kind of social project of hate so successfully in such a short time during the lockdown. But I think it can be explained by the last 20 years, especially since 2002 where the populations have

\footnotetext{
37 Ritika Jain, 'Covid-19: How Fake News and Modi Government Messaging Fuelled India's Latest Spiral of Islamophobia' (Scroll.in, 21 April 2020). https://scroll.in/article/959806/covid-19-how-fake-newsand-modi-government-messaging-fuelled-indias-latest-spiral-of-islamophobia. Accessed 15 July 2020. 38 ibid.

39 The Wire Staff, 'Coronavirus Hate Speech: BJP MLA in UP Says 'Don't Buy Vegetables from Muslim Sellers', (The Wire, 28 April 2020). https://thewire.in/communalism/suresh-tiwari-bjo-muslim-veget ables. Accessed 15 July 2020.
} 
been separated socially, economically, and most importantly at an emotional level, that it is possible to believe the worst about the other.

MAB: In 'Wages of Communal Violence', 40 among other things, you proposed that three conditions must exist for the occurrence of sectarian violence - deliberately manufactured hate, organisation to execute violence, and State complicity. How would you calibrate this theoretical insight in the context of the localised and individualised incidents of lynching? How would you situate the role of the State? Does it follow the same logic?

HM: Let me just reiterate very briefly what my thesis has been. My engagement with communal violence has been in many capacities. First, as a civil servant in charge of law and order right from 1984, when I was a young officer during the antiSikh riots in Indore. As an officer, I was also on duty when a series of communal instances happened around the Ram Janmabhoomi movement led by L.K. Advani. ${ }^{41}$ So, my understanding of communal violence comes from an intense experience of someone who not only has had a ringside view but has also been an intervener. I have seen and understood the role of the State, as well as the other factors that play an important role in communal violence. My second capacity, since the 2002 Gujarat violence, has been as a human rights worker for justice with the survivors and community workers. The third has been in the capacity of a researcher - reflecting, thinking, meditating, agonising, and theorising about communal violence. I have tried to engage with various questions - what causes communal violence, what is the lived experience of the people, why does justice fail, and what are the necessary conditions of reconciliation? My thesis has emerged in these three capacities.

Stated briefly, I have argued that there are two necessary conditions for communal violence to occur. I call these the 'manufacture of hatred'. I find a lot of echoes in the work of scholars like Paul R. Brass. ${ }^{42}$ I use the word 'manufacture' very cautiously, advisedly, and mindfully because it is truly amazing to me how hatred is actually manufactured. It is really like a chemical reaction of putting these things together and achieving something very different. You see over and over and over again right from the stories of the Partition violence. The classical ways of manufacturing hatred like building a temple in the place of Muslim worship, to the rumours of large-scale killings, or slaughter and rape by people of the other community, are ubiquitous. The most dramatic example, which I think scholars will need time to study, is how within days of the lockdown, hatred was manufactured against Indian Muslims across the country in such a powerful and effective way. This is an example of the manufacture of hatred out of falsehood in a time of unprecedented crisis. In the 1984 anti-Sikh violence, while it is true that two Sikh bodyguards assassinated Mrs. Gandhi, the hatred behind the violence was built around the stories of largescale celebration and distribution of sweets by Sikhs to celebrate the assassination of

\footnotetext{
${ }^{40}$ Harsh Mander and others, 'Wages of Communal Violence in Muzaffarnagar and Shamli' (2016) 51(43) Economic \& Political Weekly 39.

41 About which I have also written a short memoir in the sense of one of those riots in my book Unheard Voices. See Mander (n 1) 188-205.

42 See Brass (n 12).
} 
Mrs. Gandhi. There may have been stray incidents but most of it was manufactured and a complete falsehood. The Bhagalpur violence is another instance. In Bhagalpur, this country has seen one of its worst slaughters after independence. Much of the slaughter of Muslims was driven by the rumour that Hindu students have been killed in large numbers in their hostels in Bhagalpur town. Not a single student was actually killed, but the way in which this rumour spread across the district - long before the age of the Internet - stirred the mobs to slaughter their neighbours with so much cruelty. There are organisations like the RSS that have the power and reach to successfully penetrate the hearts and minds with prejudice and hatred targeted against Muslims and Christians in a way that is incomparable to anywhere in the world. I am sure it would be equally true of the role of Jamaat-e-Islami in fostering hatred in Bangladesh. Thus, the manufacture of hatred is definitely the first necessary condition.

The second condition is the actual logistics of organising the violence. Violence of any scale is never spontaneous. There again, Paul Brass has done very valuable work on 'riot-producing' machinery in the cases that he has studied. ${ }^{43}$ It isn't by chance that a collection of houses is blown-up with large numbers of cooking gas cylinders or with a large quantity of petrol, or the kind of weapons and chemicals that are used in the violence. These are not something that people happen to have. Voters lists were used in many of the large massacres in 1984 and 2002. It is not that ordinary people suddenly get enraged. Preparation is required to conduct the slaughter that we have witnessed.

My observation has very strongly been that both of these are necessary but not sufficient conditions. The sufficient condition for violence to happen after these two conditions are met is the supportive or enabling role of the State. However much hatred has been manufactured, whatever the large and effective planning may be, it cannot happen beyond the initial stage, unless the State wants it to happen. This is because the law empowers the local magistrates and the police with more than sufficient powers to control even the largest communal massacres if they choose to do so.

It is a lesson I learnt very dramatically in the first episode of communal violence that I dealt with as a young officer in Indore. That has what convinced me - and has been confirmed over and over again in every communal riot I have seen, worked with and studied the role of the State. I was posted as a young officer of just four years of service. I had never seen or dreamt that I would see anything like a large communal riot. My Collector at the time after Mrs. Gandhi was assassinated was the Additional District Magistrate. He and the Superintendent of Police called a meeting of all of us the morning after Mrs. Gandhi was assassinated at 6 am and said, 'No one will use force under any circumstances, unless I personally order it.' And then he just disappeared. This was long before we could have conversations on our mobile phones. By 12 noon, the violence started. It took that amount of time for all the preparations that I am speaking about - spreading of rumors and the preparation of the logistics. And then, for a couple of hours, I saw the worst kind of violence in my life that I never imagined I would see. Every time I asked the police

${ }^{43}$ ibid. 
to intervene, they replied, 'We are under orders not to act.' At that point, I recalled what I had learnt in my training that the senior-most magistrate has the right to call in the army to control communal violence if it is not possible for the administration to do so. The Mahua cantonment is about an hour's drive. I called the Major General there and said, 'Sir, I want you to come immediately.' He asked me if I was prepared to put it in writing. I told him that that I definitely would. He told me that his soldier columns were ready and drove in six lines of armed soldiers. I gave orders of imposing a curfew in this area at all costs. They took me on my word and took action to control the riot of the scale you saw in Delhi. It took them an hour and a half to impose complete curfew over the city. They shot 25 people. And then, everybody was indoors under a total curfew. All this happened in a space of six hours.

This was a young greenhorn officer who had no experience whatsoever. It was possible for me to do this in this short period of time in a communal massacre of that scale. So, when you then hear that something like the Gujarat riots happened where the entire state administration is under the control of the Chief Minister and the violence continues not for hours but days, weeks and in some cases for months - it is only possible because the State wanted it. You should not need any evidence of active complicity on behalf of the State in such circumstances. During the investigation, Mr. Narendra Modi actually held a meeting where Sanjiv Bhatt was present where he said, 'Let people vent their anger against the Muslims. ${ }^{44}$ It is not necessary in my opinion that you have to prove that. There is a term in law - res ipsa loquitor - facts speak for themselves. Justice Verma used that term during one of the NHRC proceedings that he was leading. ${ }^{45}$ I think you don't need further evidence of the criminal complicity of the State, because the facts speak for themselves if the violence goes for any length of time beyond merely a few hours. As I said, in my thesis, the first two conditions are necessary but not sufficient. The third condition is the decisive factor that is behind communal violence.

You have asked me an interesting question about how this theory applies to incidents of lynching. In many ways it applies entirely. Let us talk about the manufacture of hatred. In every case we have seen there is a systematic set of rumors that are spread about particular people having slaughtered a cow. In some cases, you can even pin down precisely where this rumour started. For example, Akhlaq was killed after there was the announcement in the temple that he had slaughtered a cow. ${ }^{46}$ In Hapur, again it was an announcement from the temple that a cow had been

\footnotetext{
44 This was a part of Sanjiv Bhatt's affidavit to the Supreme Court. The Supreme Court made a note of Bhatt's said allegations, that were filed before it through an affidavit on 14 April 2011 in Jakia Nasim Ahesan and Another $v$ State of Gujarat and Others Special Leave Petition (Criminal) No 1088/2008, in Sanjiv Rajendra Bhatt v Union of India and Others (2016) 1 SCC 1 [4, 6]. See Sanjoy Majumder, 'Narendra Modi 'Allowed' Gujarat 2002 Anti-Muslim Riots' (BBC, 22 April 2011). https:// www.bbc.com/news/world-south-asia-13170914. Accessed 15 July 2020.

45 NHRC, 'NHRC Makes Preliminary Comments and Recommendations to the Government of Gujarat and Government of India'. https://nhrc.nic.in/press-release/nhrc-makes-preliminary-comments-andrecommendations-government-gujarat-and-government. Accessed 15 July 2020.

46 Abhimanyu Kumar, 'The Lynching That Changed India' (Al Jazeera, 5 October 2017). https://www. aljazeera.com/indepth/features/2017/09/lynching-changed-india-170927084018325.html. Accessed 15 July 2020 .
} 
slaughtered. ${ }^{47}$ Similarly, WhatsApp messages were used to spread rumours in many other places. The manufacture of hatred is very clear and necessary to begin any communal violence. In one case where I found it very dramatic was an incident of the targeting of some Christian tribals in Jharkhand. There's a tradition in the tribal communities that if an animal that you own dies, it becomes a part of the commons. Before the animal decays, there is a window of a few hours for people to carve out the meat. There is a tradition that people will just give a call saying that my animal has died, and people rush from all over the village to carve out their evening meal from the animal. This has been going on for generations. The same thing happened in this village. In this case, some caste Hindus spread the rumor that the cow was deliberately killed. A group of four men were caught and lynched very badly, with one of them dying. ${ }^{48}$ So the manufacture of hatred clearly applies to the incident of lynching.

The same applies to the organisation of violence. Crowds do not naturally occur. They are always organised in every single case if you track them down. Whether the crowds gather spontaneously in each of these incidents, or whether they are also garnered and collected, is something I think needs a more careful study. I would be very surprised if in any case there is no logistical preparation and support for each of such episodes of lynching.

And the role of the State in the act of lynching again is entirely decisive. In a large majority of these cases, I could see the police in uniform present and not intervening. Even when they are not physically present, every story that we have followed has accounts of people desperately trying to contact the police, and the police deliberately not coming or coming too late. In some cases, such as in the incident of Hapur, ${ }^{49}$ we have visuals of a man being very badly lynched and desperately asking for water. When the police finally arrived, instead of taking him to the hospital and arresting the culprits, they tied him with ropes and dragged him like an animal on the ground. This led to his death. What is also common in any incident of communal violence is the role of the police. In every episode of communal violence, without exception, they seem to take the favour of the attackers while criminalising the victim. That is precisely what had happened in lynching.

\footnotetext{
47 Ananya Bhardwaj, 'Pierced with Screw Drivers, Scraped with Sickles: How a Muslim Trader Was Lynched in UP' (The Print, 26 June 2018). https://theprint.in/politics/how-a-muslim-trader-was-lynchedin-up-pierced-with-screw-drivers-sickles/75169/. Accessed 15 July 2020.

48 Harsh Mander, 'Four Months After Oraon Man is Lynched in Jharkhand, Bafflement at How Neighbours Could be so Brutal' (Scroll.in, 6 September 2019). https://scroll.in/article/936397/four-month s-after-oraon-man-is-lynched-in-jharkhand-bafflement-at-how-neighbours-could-be-so-brutal. Accessed 15 July 2020.

49 Bhardwaj (n 47).
} 
From the evidence, we have seen that a vast majority of the hate crime incidents have happened after Mr. Modi came to power. ${ }^{50}$ Somebody might say, is it really my charge that Mr. Modi and Mr. Shah sit down every morning and organise episodes of lynching? This is not what I am claiming. What I am claiming is that they have created an environment that normalises, legitimises, and valorises hatred. It also communicates that if you lynch people in the name of the protection of the cow or love jihad, you are actually the hero of a "Hindu nation", and that the State will do all it can to protect you. This encouragement of hatred is the larger all-encompassing role of the State. And then you have the more specific enabling role of the State through the actions of the local officials.

MAB: In fact, in your recent work, you have described these incidents not just hate crimes, but 'command hate crimes' because they emerge from structural, environmental, and institutional contexts. ${ }^{51}$

HM: Yes. And where institutions encourage and valorise attackers by protecting them, and by criminalising and victimising the victims.

MAB: In the many accounts of sectarian violence in your writings, one of most striking things is the quality of violence. This is not just killing, but extreme forms of indignities and torture. There appears to be something deeply pathological about this kind of violence.

HM: There is extreme cruelty in episodes of communal violence. In my latest book Between Memory and Forgetting ${ }^{52}$ on the Gujarat massacre, I graphically recreate some of the stories. It is so hard when you see the story of Bilkis Bano. People of her village - with whom she has grown up - gathered, stripped them naked, raped people, smashed the heads of children. In Naroda Patia, we had a boy who was made to drink petrol and explode with a matchbox. And this sexualised taunting that we have heard even right now, with the rioters in North East Delhi coming and stripping themselves, exposing their genitals, and taunting people. ${ }^{53}$ There is an intense pathology in the nature of a communal violence over many decades.

It is the same pathology but perhaps it is in even more sharp relief in lynching. In Karwan-e-Mohabbat we have made a resolve that we will visit every family who has been a victim of lynching, share their grief, seek forgiveness, and provide solidarity in their battle for justice. I recall one family telling us, 'Bas aise hi maar dete. Goli mar dete. Churra maar dete hai. Itna torture karke kyun mara? (They should have

\footnotetext{
${ }^{50}$ For data on the increasing number of hate crimes since the BJP came to power in 2014, see Anne Gowen and Manas Sharma, 'Rising Hate in India' (The Washington Post, 31 October 2018). https:// www.washingtonpost.com/graphics/2018/world/reports-of-hate-crime-cases-have-spiked-in-india/. Accessed 15 July 2020. According to a study conducted by India Spend, 'as many as $90 \%$ of religious hate crimes since 2009 have occurred after the BJP took power at the Centre in 2014', cited in Harsh Mander, 'New Hate Crime Tracker in India Finds Victims are Predominantly Muslims, Perpetrators Hindus' (Scroll.in, 13 November 2018. https://scroll.in/article/901206/new-hate-crime-tracker-in-india-finds -victims-are-predominantly-muslims-perpetrators-hindus. Accessed 15 July 2020.

51 Mander (n 35).

52 Harsh Mander, Between Memory and Forgetting (Yoda Press 2019).

53 Naomi Barton and Srishti Srivastava, 'They Took Down Their Pants, Pointed Their Genitals at Us, and Said, 'Yeh Lo Azaadi', (The Wire, 3 March 2020). https://thewire.in/women/delhi-riots-women -sexual-harassment. Accessed 15 July 2020.
} 
just killed them. Shot them. Stabbed them. Why did they torture him so much?)' Why did they gouge out his eyes, smash his genitals? In one of the cases, when the family received the dead body of the victim, they found that the perpetrators had actually cut his penis as a taunt. It is those cruelties. And the kind of sadistic pleasure in actually video-taping it. In many video-tapings of lynching that we have seen, there is a certain pattern of how people hit the victim. In some videos, I have seen the victim ask for water, and the perpetrators take joy in not giving water. The victim finally becomes unconscious and dies. It is this collective cruelty. Many of these mobs have young people, even children well below the age of 18 years.

The question that you are asking is where is this hatred or cruelty coming in from? I feel the era of lynching marks a decisive change, where the manufacturing of hatred has become almost a national project with a high degree of support from the highest political authority. NDTV recently conducted a VIP hate speech survey - hate speech by influential persons - where they found a leap of something like 500 percent in the amount of VIP hate speech that has happened in the Modi era. ${ }^{54}$ Hate speech of the worst kind is taking place in the presence of or from the highest offices themselves, including chief ministers, union ministers, and occasionally even the Prime Minister. We have seen that the manufacture of hatred - its normalisation, legitimisation, and most of all its valorisation - is the real social project since 2014. So, there is a local manufacture of hatred but it is located within this much larger nationwide normalisation, legitimisation, and valorisation of hate that we are living in within these times.

MAB: I wanted to ask you about how the law figures into this. You and many others have argued that the way to deal with the problem of State complicity and impunity cannot be to further strengthen the arms of the State. You had critiqued the United Progressive Alliance's (UPA) ill-fated Communal Violence Bill. ${ }^{55}$ Your argument was that the law against sectarian violence must not give more power to the State, but rather provide more legal accountability. But isn't the law - even in the form of legal accountability - only further strengthening some institution of the law against other institutions of the law? Take the example of hate speech. Criminalisation of hate speech has shown us that the law is invariably used not against those who essentially spur hatred but for everybody else. ${ }^{56}$ We do not want to empower State institutions but it seems that law is the only way to do it; it perhaps invariably does exactly that even if we frame it as accountability. Democracy would have been a very good mechanism of addressing this but it seems that it has failed altogether. So, there are three questions here. First, how do we bring in State accountability and can the law do it? Second, what are the limits of the law in this intervention? Third,

\footnotetext{
54 Nimisha Jaiswal, Sreenivasan Jain and Manas Pratap Singh, 'Under Modi Government, VIP Hate Speech Skyrockets - By 500\%' (NDTV, 19 April 2018). https://www.ndtv.com/india-news/under-naren dra-modi-government-vip-hate-speech-skyrockets-by-500-1838925. Accessed 15 July 2020.

55 The Prevention of Communal and Targeted Violence (Access to Justice and Reparations) Bill, 2011.

56 See Prabhir Vishnu Poruthiyil, 'What 'Hate Speech' Really Means, and How the Term is Being Misused' (The Wire, 8 March 2020). https://thewire.in/rights/hate-speech-sangh-parivar-protests. Accessed 15 July 2020.
} 
why has democracy failed and can we think of democracy in a different way that would bring in some system of accountability?

HM: These are the most difficult questions you have asked in this conversation. They present the most painful dilemmas. From the first episode of communal violence that I handled and during the subsequent series of events I have witnessed, I was very struck by one irony. The greatest complaints of people - survivors of communal violence, who were mostly people from the minorities - were against the police. And yet their strongest demand everywhere was for police pickets and police thanas (stations) for their protection. It struck me that they had the greatest anger against this institution's criminal betrayal of its duty. And yet this was what they felt they needed in order to be safe in the future.

At the larger level, I do think that at the end, in a democracy, we have to fight communal hatred as a social project deeply embedded in philosophy and ethics, and examine the nature of the social contract itself. In a political project, we understand that democracy is not about the will of the majority but very substantially also about the protection of the rights of the minorities. We have to build a set of political rules that will protect the rights of the minorities against the majoritarian onslaught of the kind that we have seen in India. But I think that whatever our difficulties and problems with the institutions of law may be, there is no turning away from embedding in law the normative standards for public servants, including the punitive consequences for those who fail to uphold their duties.

Let me try to explain the arguments of why we felt a communal violence law was required, but one very different from the kind that was presented by the UPA government. I would also like to mention the rocky journey we had in the National Advisory Council where we presented a very different draft, and why it never saw the light.

The fact that right through the history of independent India, very few people have actually faced punishment for communal violence is not simply an accident or a failure. It is a success because impunity is as much planned as the massacre. L.K. Advani, as the Home Minister in Vajpayee's government, made a statement after the Gujarat pogrom. He said that it isn't that the criminal justice system deliberately failed to punish the guilty. He said that the criminal justice system is generally so badly broken that it fails to secure justice. ${ }^{57}$ I found it odd for the Home Minister to just make this claim that the justice system is unable to deliver justice normally as well, and to say that unproblematically. But I argued, responding to him saying that this was not true. ${ }^{58}$ It is not State failure but State success because impunity is what the State set out to ensure, and it has been spectacularly successful in doing that. We find a very clear pattern of systematic ways in which impunity is ensured at every stage. The first is delayed First Information Reports (FIRs). After incidents of mass

\footnotetext{
57 LK Advani to journalist Karan Thapar, 'Hard Talk India: LK Advani 10 October 2003' (22 February 2012). https://www.youtube.com/watch?v=VVz2WNI_DbU. Accessed 15 July 2020.

58 Harsh Mander, 'State Subversion: Gujarat's Victims Completely Isolated' (The Times of India, 22 November 2003). https://timesofindia.indiatimes.com/edit-page/LEADER-ARTICLEBRState-Subversion -Gujarats-Victims-Completely-Isolated/articleshow/295528.cms. Accessed 15 July 2020.
} 
violence, people are in relief camps in devastated situations. If the police wanted, they could reach every individual in the camps and actively encourage them to file FIRs. Instead, what tends to happen is that in almost every incident, the police themselves register reports. The character of these reports tends to be of two kinds. First, it tends to be an omnibus. So, 50-100 episodes of violence are crammed into one, which makes later investigation, charge sheeting, and prosecution extremely complicated. And they are literally ambiguous. These state that an 'unarmed mob' or 'angry mob' engaged in violence. The FIRs are framed as if these mobs had almost justifiable anger. For example, the police would write - angered by the burning of the train in Godhra, or in 1984 angered by Mrs. Gandhi's assassination. The police are very careful so as to not include any details of who constituted the mob, and who the witnesses were. It is so striking because this delayed omnibus and ambiguous FIRs is something that you find across so many episodes of communal violence. When I saw this happen in Delhi again, I told my colleagues that there must be a secret manual somewhere that instructs the police to ensure impunity in precisely the same ways.

After filing such FIRs and engaging in inaction masquerading as investigation, the police can either close the case or file a charge sheet. What we found in Gujarat and other instances is a pattern. ${ }^{59}$ A large majority of cases would be closed without filing a charge sheet, essentially stating, 'Yes, the crime had happened but we do not know the culprits.' There would be no names recorded, no evidence collected, no witnesses known. I had personally, with Indira Jaising as my advocate, found that more than 2000 FIRs - around half of the total registered FIRs - had been closed. ${ }^{60}$ I challenged this massive omnibus closure of cases in the Supreme Court. ${ }^{61}$ The Court finally authorised the reopening and reinvestigation of all the closed FIRs. I could go on about the many ways in which impunity is ensured.

Coming to the UPA draft of the Bill to prevent further communal violence. This was a promise that they made when they were elected. What they effectively did was to add further to the powers of the police, specifically for enforcement in disturbed areas, and other powers that one typically associates with anti-terrorism laws. So, the Bill empowered the State to act, to arrest, to take a number of steps that are extraordinary and in contravention with standard principles of due process and human rights. The government claimed that only if the police have this kind of additional power will they be able to control the violence. My argument, and that of the others who opposed the Bill, was simply this: did they really think that Mr. Modi and his state government in Gujarat did not control the riots because they did not have the powers to do so? Or was it because they did not have the will to do it? Did the violence in 2002, or 1984, or any during any other incident of violence

\footnotetext{
59 See for eg Human Rights Watch, Discouraging Dissent: Intimidation and Harassment of Witnesses, Human Rights Activists, and Lawyers Pursuing Accountability for the 2002 Communal Violence in Gujarat (2004) 7.

60 See n 4.

61 ibid.
} 
continue because the State was powerless or because it had a project - a pogrom to execute?

This has been my personal experience in all the major communal violence incidents that I have witnessed since the 1984 riots. Not me alone. There was somebody like Rahul Sharma who curtailed the violence in Gujarat. ${ }^{62}$ When I talked to him, I found that he did exactly what I had done in my district during the 1984 riots. In fact, there were so many echoes when we re-counted. He was able to control the violence in the shortest possible time. This goes back to the point that it is not that people do not have enough powers to control the violence. Even a young greenhorn officer in a very small district, with very little force at his disposal, is able to effectively control large episodes of communal violence. Adding more powers is only going to be used against the very minorities that the law actually means to protect.

We argued that the law does not need to empower the State any further than it already does. Rather it must empower the victims and survivors to demand accountability from the State. So, the most important single thing that we tried to put into the law was a different idea of creating a new crime - the crime of culpable inaction of public officials linked to the idea of command responsibility. We argued that most incidents of communal violence happen because of the culpable inaction of public officials under command from above, and only the recognition of these as a crime can prevent violence.

Whether the same institutions in the police or the judiciary would allow the application of these provisions remains one of those difficult questions that I flounder to answer. But having worked in the civil services, I am quite certain that a large majority of civil servants are hugely risk averse. The moral responsibility to be fair and to protect lives in communal violence does not seem to work. But the fear that one day a regime could come that might punish them under these provisions of culpable inaction would, I hope, push a large number of civil servants to do their duty.

MAB: Let us move on to the third theme of our conversation related to the legal strategy to address hate crime. I would like to ask you about your experience with Nyayagraha, which as we know is an acclaimed and powerful experiment in justice and solidarity. In Nyayagraha, you conceptualised the role of Amanpathiks (peace workers) as people who help survivors come to terms with their suffering and loss and to bring the estranged communities together as one project. You also conceptualised the role of Nyayapathiks (justice workers), who link this work with legal justice, as people who 'would walk the path of justice. ${ }^{93}$ So Nyayagraha, as a project and ideal, is a way to bring legal and social justice together. How would you reflect on Nyayagraha as a form of legal strategy for justice in hate crime cases? Why is it crucial to integrate the legal and the social in this strategy?

HM: Let me start with the birth of Nyayagraha. I found that after the Gujarat pogrom, even after getting all the closed FIRs reopened through the Supreme Court, in most cases the police reinvestigated and then closed the cases all over again for

\footnotetext{
62 Rana Ayyub, Gujarat Files: Anatomy of a Cover Up (2016) 84.

${ }^{63}$ Harsh Mander, 'Survivors of Mass Violence and the Idea of Justice' in Patrick Hoenig and Navsharan Singh (eds), Landscapes of Fear: Understanding Impunity in India (Zubaan 2014).
} 
nearly the same reasons as before. But even in the cases that did go to trial, it was such an adverse setting for victims and survivors. There was an extremely hostile social political environment. And the courtroom itself was a site where the secondclass citizenship was played out so openly. It seemed almost a hopeless task.

A couple of years after the massacre, I took a big decision to relocate to Gujarat for some months. I spent almost a year there. I spent my time with the survivors, the volunteers, the Amanpathiks, the Nyayapathiks, and many people from the community. We tried to craft the strategy together.

Nyayagraha is an idea that I drew from Satyagraha. Satyagraha is a political instrument of resistance against unjust laws. But in this context, it was not the law that was unjust but the implementation of the law by the state instruments that was the problem. So, I thought of calling it Nyayagraha - a demand for justice. It was founded on, firstly, that means are very important. If the battle is for truth and justice, the means at every stage, and in every respect, must follow the same ethical principles. In a very real and tangible sense, it meant the following. I went from village to village, and camp to camp with my colleagues, to have meetings with communities. We started off with the question of informed consent. We used to say that it is very hard for the victims and survivors to fight for justice. We should not look down upon those who have to re-negotiate their lives and decide that they do not want to pursue justice. Everyone who wanted to fight for justice must really want to do it. We told that that we will stand with you if you so choose to fight.

Once the informed consent was coming, we would say that we also had certain conditions. We would say that since it is a fight for truth and justice, we have to pledge that we will have to fight this entire battle through the principles of truth and justice. This translated into two practical rules. One is that at no stage in the legal battle will we be willing to offer a bribe to anybody to get any favours. Second is that we will never lie in any testimony, even if it leads us to lose the case. I had many senior lawyer colleagues who said, 'We simply cannot understand these two rules!' They said that we were already fighting such an unequal battle with the State. And then we wanted to further tie up our hands and our legs. But it remains a very fond memory that in working class communities where we used to have these discussions, people used to understand what we were saying. They actually felt strengthened in a very ethical kind of way. Their morale was increased. They felt that they were truly fighting a battle for truth and justice. And they would always give their pledge. Our witness preparation then became a very simple job. During our witness preparation, we would tell them one clear principle of 4 words - 'Sach bolo, saaf bolo (Speak the truth and speak it clearly).' That is all that we have to say.

There is so much mayhem in episodes of communal violence. People do not know what is going on and everyone is trying to save their lives. In all that mayhem, it is not always possible that the victims and survivors manage to see someone doing something. So, what sometimes happened in these cases is that the lawyer would sit you down and say, 'Okay, this is the accused and you have not actually seen him. We know that. But you have to say, "I did not run away; that actually I was hiding behind a wall or behind a tree and I saw this person doing something." But what we told the witnesses was, if you ran away during the violence, you ran away. If you did not see the accused, you did not see the accused. Under no circumstances will 
you say that you saw the accused. Once it became clear that I have to only speak the truth and speak it with clarity, it became a different kind of battle.

We also realised that the outcome of a large majority of the cases is not determined exclusively or even overwhelmingly by what is transacted in the courts. A great part of the outcome is actually determined by what happens in the community, because it is here that the victims and survivors and witnesses are often living in the shadow of the community and individuals who have caused harm. They continue to wield power, and can intimidate, threaten or bribe. The word compromise or 'compro' has become part of the local Gujarati parlance. I wrote a long essay on compromise in Gujarat, ${ }^{64}$ where I tried to describe how these compromises are transacted. I wrote it partly in defence of Zahira Sheikh, the 19-year-old woman in the Best Bakery case ${ }^{65}$ caught in difficult circumstances. One cannot understand what it means to be placed in the midst of all of these winds blowing and tossing you here and there. We might make a morally unwise choice in these circumstances.

Another important part of Nyayagraha's approach is the community justice worker or the Nyayapathik. I consciously avoid using the term paralegal, because it seems to suggest that somehow you are subordinate to the lawyer and perform less important tasks. What we used to say was that the lawyer and Nyayapathik are both specialists. The Nyayapathik is the specialist on what happens in the community, and the lawyer is a specialist on what happens in the court. Because a large part of what is going to happen in the court depends on the kinds of pressures and negotiations that are happening in the community prior to the case, it is the Nyayapathik who builds the relationship of trust and support for the victims and survivors. She is the one who takes informed consent and support from the victims and survivors, provides support in order to enable them to stand strong, and ultimately accomplishes 'sach bolo, saaf bolo' in the court. Those are the major parts of our legal strategy as conceptualised under the Nyayagraha idea.

MAB: How would you reflect on Nyayagraha from the perspective of your interventions and campaigns under the banner of Karwan-e-Mohabbat? One of the important themes in Nyayagraha was the expression of ethical courage, which among other things had the power to bring about moral change in institutional actors and even sometimes in the perpetrators. You have written about how initially the police officers disrespected and disregarded the Nyayapathiks. The Nyayapathiks were asked to stand in a corner and not allowed to collect documents for the cases. But eventually, even the police officers acknowledged their moral power. They started to treat the Nyayapathiks from 'undisguised hostility to grudging respect. 66 This was very similar to how Gandhi imagined Satyagraha, in terms of bringing a change in the hearts and minds of the colonial oppressor. Has this succeeded from your experience with Karwan-e-Mohabbat? In your recent writings on the challenges in dealing with the lynching cases, you note that there is complete absence of

\footnotetext{
${ }^{64}$ Harsh Mander, 'Broken Lives and Compromise: Shadow Play in Gujarat' (2012) 47(8) Economic and Political Weekly 90.

65 See Zahira Habibullah Sheikh and Others $v$ State of Gujarat and Others (2006) 3 SCC 374.

66 Harsh Mander, Fear and Forgiveness (Penguin India 2009) 166.
} 
any remorse or guilt on the part of perpetrators. Do you think the current moment reflects the limits of the Nyagraha approach?

HM: A lot of my friends and comrades in the legal fraternity used to reflect a lot on this whole idea of the Nyayagraha approach. A significant proportion of them were never convinced about the strategy at all. In fact, Dr. Upendra Baxi ${ }^{67}$ and Dr. Ram Kumar were the few people who took it seriously, and engaged with some of these ideas at a reflective and contemplative level. The others thought that this business of engaging the ethical in the midst of this fraught and unequal legal battle makes it even harder to win the case. But I often had discussions with my largely working-class colleagues who became Nyayapathiks and Amanpathiks. I used to delight in the moral clarity of the discussions that we often had together. We actually lost a very large number of cases that we fought. But my colleagues would say that we did not actually lose those cases, we won them in many ways. We won them because the victims and survivors and we stood together on a moral plane. They said that this was a battle against a sense of despair, against a communal pogrom that took away from them even the idea of their humanity and equal citizenship. And in the process of engaging in this battle, they reclaimed their sense of humanity and citizenship. The legal system does not work for the majority of poor people. It also did not work for us. But in the way we were able to engage it affirmed for us a sense of both humanity and citizenship. The victims and survivors were not simply witnesses who had been trained just before their statement, but people who were the drivers of a righteous, non-violent, democratic, morally bound battle for justice. In the end, it helps the victims and survivors - who are treated with the worst of indignity and inhumanity - to engage and assert themselves as moral agents. It was becoming a moral agent, about influencing your adversary to engage on moral terms. And therefore, however adverse the circumstances, I do believe that a true battle for justice and human rights has to be founded on the principles of truth, justice, solidarity, and compassion.

MAB: You have been a great chronicler through your stories. Recently in your writings on Karwan-e-Mohabbat, you invoke the powerful story of Maulana Rashidi, ${ }^{68}$ who lost his son in sectarian violence in Asansol but exhibited great courage by stopping people from his community from engaging in violence. There are numerous other powerful and inspiring stories you have written and spoken about. In your experience, what impact do these stories have on the readers and listeners, especially those who have suffered such gruesome violence? What role does this chronicling and storytelling have in building solidarities and in changing hearts?

HM: It's a great question. I am deeply committed to storytelling for many reasons. When she was given a lifetime achievement award at the Golden Globes, Meryl Streep talked about the importance of cinema as a form of storytelling and as a vehicle of empathy. Solidarity is founded on our capacity for empathy. I think

\footnotetext{
${ }^{67}$ Upendra Baxi, 'Review: Revisiting Gujarat 2002 with Harsh Mander' (2010) 45(14) Economic and Political Weekly 32.

${ }^{68}$ Harsh Mander, 'Miracles in Asansol: As Coal City Burnt in Hatred, a Muslim Cleric and Hindu Temple Healed With Love' (Scroll.in, 12 April 2018). https://scroll.in/article/875325/miracles-in-asansolas-coal-city-burnt-in-hatred-a-muslim-cleric-and-hindu-temple-healed-with-love. Accessed 14 August 2020.
} 
we have created a world between ourselves, with walls so high that it is harder and harder for us to even imagine what life would be for a person who lived in different circumstances from ourselves. This is why right now during the COVID-19 pandemic lockdown, middle class people — who are so comfortable - do not feel outrage that the poor people do not have houses that they can be locked in, cannot maintain social distancing, and cannot live without work. The fact that we have no empathy for people who live in very difficult circumstances is why we have so little solidarity. I consciously began storytelling when I joined as a faculty member at the Lal Bahadur Shastri Academy to train the young recruits to the civil services for three years from 1993 to 1996 . I had taken upon myself to talk to them a lot about communal violence, and about Dalits, hunger, and deprivation. I found that people were not able to imagine what life is like for people in very different circumstances. That is when I started writing my first stories, which actually came together later in my first major publication called Unheard Voices. ${ }^{69}$ The book had the stories I wrote for my students in order to help them empathise with what it means to be Dalit, or a survivor of sectarian violence, or a woman who was gang raped.

I have also seen the value in the process of sitting with a person who has suffered a great deal of injustice and whose very humanity has been assaulted. I often talk to my students about a triangle with which one needs to approach people who have suffered great injustice - respect, curiosity, and empathy. You have to be really interested in that other person, you need to have unconditional respect for that person, and through this process of storytelling there is a construction of empathy. Then you begin to recognise that a human being is not a category to be studied. She is not a problem to be solved. She is not a cause to be upheld. As a social scientist, she is not a statistic to be gathered and analysed. She has her full humanity and individual dignity. And this is how we must approach her. So, while you are working with people affected by communal violence, each individual is coping with it in her own kind of way and own kind of understanding. To understand that experience, and to give it weight and respect, is very re-affirming or the person who has lived through that extreme suffering and injustice. They feel a sense of acknowledgement and affirmation. Many people have told me that the process by which we constructed a story together became a very important moment in their own lives. Those were moments of recognition, of reaffirmation to them about their own worth. Storytelling for me is also important because of this kind feeling, affirmation, and demonstration of respect and equality that it can at its best nurture.

Publisher's Note Springer Nature remains neutral with regard to jurisdictional claims in published maps and institutional affiliations.

${ }^{69}$ Mander (n 1). 